\title{
Micro-electrophoresis of Cowpox and Vaccinia Viruses in Molar Sucrose
}

\author{
By H. W. DOUGLAS, C. J. M. RONDLE AND B. L. WILLIAMS \\ Departments of Bacteriology and Chemistry, \\ The University of Liverpool
}

(Received 27 July 1965)

\begin{abstract}
SUMMARY
Preparations of cowpox and vaccinia viruses, grown on rabbit skin and on chick chorioallantois, purified by methods involving Arcton treatment or centrifugation in sucrose density gradients gave electrophoretically reproducible materials. A micro-electrophoresis technique is described with which measurements may be made conveniently and reproducibly on individual virus particles suspended in buffered molar sucrose solutions. The viruses had a mobility of approximately $-0.4 \mu / \mathrm{sec} . / \mathrm{V} . / \mathrm{cm}$. in molar sucrose at $\mathrm{pH} 7$ and ionic strength $0 \cdot 05$, their negative charge decreasing with decreasing $\mathrm{pH}$ value to give isoelectric points at $\mathrm{pH} \mathrm{4.3}$ for cowpox, 3.7 for egg-grown vaccinia and $3 \cdot 0$ for rabbit-grown vaccinia; in greater acidities the viruses were positively charged. The results showed close reproducibility for the final preparations of cowpox of different origin and treatment, suggesting that the virus suspensions were relatively pure and free from adsorbed or extraneous material. Similar reproducibility was found for rabbit-grown vaccinia virus preparations, but there was some variation among different preparations of egg-grown vaccinia virus.
\end{abstract}

\section{INTRODUCTION}

So far as is known to the authors all previous electrophoretic studies on virus particles have been carried out either with the Tiselius moving-boundary method or with virus adsorbed on larger carrier particles. Thus Shedlovsky \& Smadel (1940) showed that under carefully controlled conditions, purified preparations of vaccinia virus migrated as single boundaries in the Tiselius cell. Similar experiments by McFarlane (1940) were hampered by endo-osmotic disturbances, a difficulty which Shedlovsky \& Smadel were able to eliminate by the addition of a small amount of protein to their suspensions. Both groups of workers arrived at about the same value, $-1 \mu / \mathrm{sec} . / \mathrm{V}$. $/ \mathrm{cm}$., for the mobility of the virus at $\mathrm{pH} 7$. No doubt the relatively large amount of purified virus required for moving-boundary experiments and the limited dispersion of virus particles at some $\mathrm{pH}$ values have been a deterrent to further studies.

In micro-electrophoretic methods, on the other hand, individual particles are observed and smaller volumes at low virus concentrations generally suffice so that, as suggested by Brinton \& Lauffer (1959), the electrophoretic behaviour of virus particles may be more conveniently and economically studied. Over many years the micro-electrophoretic method has been applied with considerable success to a variety of cells in the size range 1-10 $\mu$, e.g. bacteria and erythrocytes. No account 
has been published however of a direct application of the technique to particles approximately $0.2 \mu$ in size, though influenza virus adsorbed on much larger collodion particles was studied by Miller, Lauffer \& Stanley (1944).

There are particular difficulties with virus particles. Thus their size and refractivity limit the applicability of the general methods of illumination (brightfield, phase-contrast) and only with a critically focused dark-field condenser arrangement may they be conveniently seen. Further, their Brownian movement in water is so large that they move out of a particular focal plane with frustrating rapidity and frequency, so that continued observation is not practicable. Increasing the viscosity of the suspending medium decreases this movement, and in molar sucrose, which has approximately three times the viscosity of water, continuous observation for a sufficient period for accurate mobility determinations (about 10 sec.) becomes readily possible by using a dark-field arrangement.

The present paper describes the technique used and results obtained in an initial study of preparations of cowpox and vaccinia viruses. These viruses are of the order of $0.25 \mu$ and various methods have been devised for the preparation of purified suspensions for study of their physical and chemical properties.

\section{METHODS}

Viruses. The Brighton strain of cowpox and the Lister Institute strain of vaccinia were used. Each virus was grown on chick chorioallantois and on rabbit dermis. Virus passed at least 36 times on chick chorioallantois was used in the preparation of egg-grown virus. Virus maintained solely by dermal infection of rabbit was used in the preparation of rabbit-grown virus.

Virus purification. Virus was recovered from extracts of infected tissue by differential centrifugation and this crude material purified either by the use of Arcton (Epstein, 1958) or by sucrose density gradient centrifugation (Zwartouw, Westwood \& Appleyard, 1962). In both instances the original methods were somewhat modified. In the Arcton method, the crude virus material was shaken once only with an equal volume of Arcton 113 for $5 \mathrm{~min}$. at room temperature, and the aqueous layer containing suspended virus material then further purified by differential centrifugation for $30 \mathrm{~min}$. at $\mathbf{1 0 , 0 0 0} \mathrm{rev} . / \mathrm{min}$. in a Spinco 40 rotor. In purifying the virus by the sucrose density gradient technique $2 \mathrm{ml}$. of crude virus suspension was layered on top of a $1 \mathrm{~cm}$. band of $40 \%(w / v)$ sucrose, overlying similar bands of 50 and $60 \%$ sucrose contained in a $5 \mathrm{ml}$. Spinco tube, and the whole spun at $20,000 \mathrm{rev} . / \mathrm{min}$. for $20 \mathrm{~min}$. in an SW 39 head. The $50 \%$ layer, which contained the bulk of the virus, was removed, mixed with 2 volumes of sterile water and the virus then deposited by centrifugation at $20,000 \mathrm{rev} . / \mathrm{min}$. for $30 \mathrm{~min}$. in the Spinco 40 rotor. The supernatant fluid was replaced by molar sucrose solution, buffered to $\mathrm{pH} 7$ with phosphate buffer of ionic strength 0.001 , and the virus redispersed by ultrasonic treatment for $1 \mathrm{~min}$. with an M.S.E.-Mullard ultrasonic disintegrator. Dilution, centrifugation and resuspension were repeated until the suspended particles appeared uniform by dark-field examination, uniform after staining by the silver technique of Gispen (1952) and constant in their electrophoretic behaviour in molar sucrose at $\mathrm{pH} 7$. This was achieved after not more than 3 cycles in phosphate-buffered molar sucrose. The final virus suspensions had 
infectivity titres of $10^{9}-10^{10}$ pock-forming units (p.f.u.)/ml. when titrated on chick chorioallantois. They were agglutinated by rabbit hyperimmune antivaccinial sera. Hence for each virus four kinds of final stock preparations in molar sucrose buffered at $\mathrm{pH} 7$ were obtained; egg-grown purified with Arcton (EA); egg-grown purified by density gradient centrifugation (ES); and the corresponding materials for rabbit-grown virus (RA) and (RS).

Buffers and virus suspensions for electrophoresis. The buffers used were the acetate + veronal $+\mathrm{HCl}$ mixtures described by Michaelis (1931). For each electrophoretic experiment volumes of buffered virus suspension and of plain buffer, both molar to sucrose and of ionic strength $0 \cdot 05$, were prepared from the same intermediate buffer. This intermediate buffer was made from $5 \mathrm{ml}$. stock sodium acetate + sodium veronal solution $(0 \cdot 143 \mathrm{M}$ each $)$ + the volume of $0.1 \mathrm{M}-\mathrm{HCl}$ to give the required $\mathrm{pH}$ value, together with $5 \mathrm{ml} .0 \cdot 714 \mathrm{M}-\mathrm{NaCl}$ to adjust the ionic strength, $57 \mathrm{ml}$. 1.66 M-sucrose, and sterile distilled water added to a final volume of $95 \mathrm{ml}$. Since the micro-cell used for electrophoresis required only $10 \mathrm{ml}$. to fill it and it was important to conserve the limited volumes of final stock suspension from each batch (about $10 \mathrm{ml}$. at $10^{9}-10^{10}$ p.f.u. $/ \mathrm{ml}$.), only $20 \mathrm{ml}$. of diluted suspension (at about $10^{8}$ p.f.u. $/ \mathrm{ml}$.) were made for each mobility determination; $1 \mathrm{ml}$. of the virus stock in M-sucrose being added to $19 \mathrm{ml}$. of the intermediate buffer of the required $\mathrm{pH}$ value and ionic strength 0.0525 . In addition to the $20 \mathrm{ml}$. of diluted virus, volumes of plain buffer ionic strength 0.05 and molar to sucrose were used for flushing one suspension out of the cell before introducing the next and also for the separate measurement of $\mathrm{pH}$ and electrical conductivity.

Micro-electrophoresis cell and optics. The electrophoresis cells used were of the pattern described by Douglas $(1955,1957)$, having a channel of rectangular section, $10 \mathrm{~mm}$. wide by $0.2 \mathrm{~mm}$. deep. The cell was mounted and operated on the vertical stage of a Watson 'Service' microscope as described in the earlier papers on bacterial systems. In replacing the phase-contrast optics by the dark-field arrangement used here, a Cooke, Troughton and Simms dark-field condenser mounted in a suitable adapter replaced the normal substage condenser and a Zeiss $\times 40$ objective and $\times \mathbf{1 5}$ eyepiece (with a linear scale) were used. The internal focusing adjustment of the condenser proved most convenient in obtaining optimum dark field at the top and bottom surfaces of the cell and the associated stationary levels, where there was no movement of fluid and at which the particle velocities were determined. A useful reserve in the intensity of the light scattered by the virus particles was obtained by supplying the power to the Watson transformer and ribbon-filament lamp $(6 \mathrm{~V}, 108 \mathrm{~W})$ through a Variac transformer so that the lamp could be somewhat over-run. The determination of cell depth and location of the stationary levels were made by using a Mercer gauge (graduated to $2 \mu$ ) rigidly mounted on the barrel of the microscope and with the probe bearing against the upper surface of the microscope stage.

Measurement of particle velocities. As in previous work (Douglas, 1957), the current in the micro-cell was adjusted so that virus particles in focus at one of the stationary levels of the cell took some 10 sec. to traverse 20 divisions of the eyepiece scale, equivalent to $52 \mu$ in the focal plane of the objective. Under these conditions only a small proportion of particles initially in focus went out of focus before completing the course under the applied field; these were discounted. Particles were observed 


\section{H. W. Douglas, C. J. M. Rondle and B. L. Williams}

at both stationary levels and travelling in both directions (current reversal), and at least 32 observations were made on different particles to obtain mean mobility values. In determining the frequency distribution of particle velocities for particular suspensions, the speeds of at least 128 individuals were measured.

Electrical measurements. The current in the cell giving the chosen rate of particle movement was measured using a Cambridge Unipivot d.c. microammeter. The potential gradient in the channel of the cell was calculated from this current together with the measured cross-sectional area of the cell and the electrical conductivity of equivalent virus-free buffer determined at $25^{\circ}$ by using a Mullard diptype cell and a Wayne-Kerr B221 bridge. The $\mathrm{pH}$ values of the buffers were checked by using a Beckman model 72 meter and glass electrode.

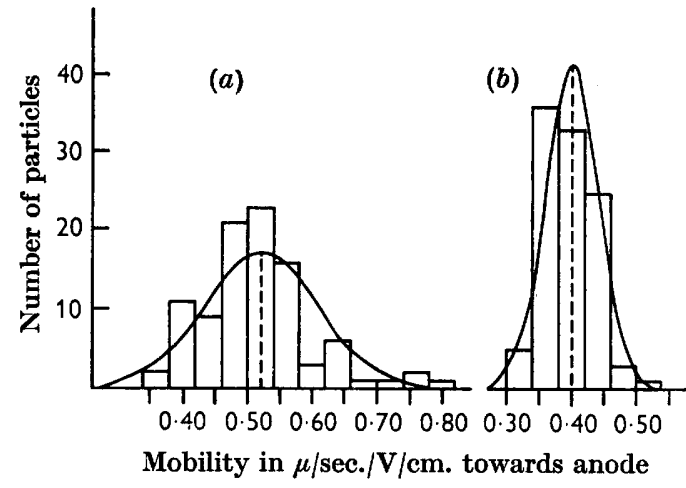

Fig. 1



Fig. 2

Fig. 1. Histograms of frequency of individual particle mobilities in $\mu / \mathrm{sec} . / \mathrm{V} / \mathrm{cm}$. (towards anode) for egg-grown cowpox preparations $\mathrm{Br}$ Ea 32 together with the corresponding normal distributions calculated from the standard deviation (s.D.) for (a) initial preparation, s.D. $=0.09$, and $(b)$ a final preparation, s.D. $=0.04$ mobility units.

Fig. 2. Mean mobility against $\mathrm{pH}$ behaviour for final preparations of egg-grown and rabbit-grown cowpox at $25^{\circ}$, in media molar to sucrose and of ionic strength 0.05 . O, RS preparation, 32;, RA, 36; $\triangle$, ES, 35; $\square, \mathbf{E A}, 32,34$.

\section{RESULTS}

All particle velocities and mean mobility values presented here refer to buffered media, ionic strength 0.05 and molar to sucrose, at $25^{\circ}$.

\section{Corepox virus}

It was essential to remove all host-cell debris during purification otherwise the light it scattered seriously hampered the observation of virus particles. Further, particulate material of different surface composition could alter the distribution of observed particle velocities and hence the mean mobility calculated for a given virus preparation. The two histograms shown in Fig. 1 illustrate this point, being typical of initial and final preparations. Washing the virus preparations narrowed the distribution of particle velocities until finally a limiting standard deviation and mean mobility value was reached. The smooth curves superimposed on the histograms are the corresponding Normal (Gaussian) distributions calculated from 
the experimental standard deviations. Mean mobility values obtained for final preparations over a range of $\mathrm{pH}$ are plotted in Fig. 2, and show the agreement between different preparations obtained by one method and by different methods of purification.

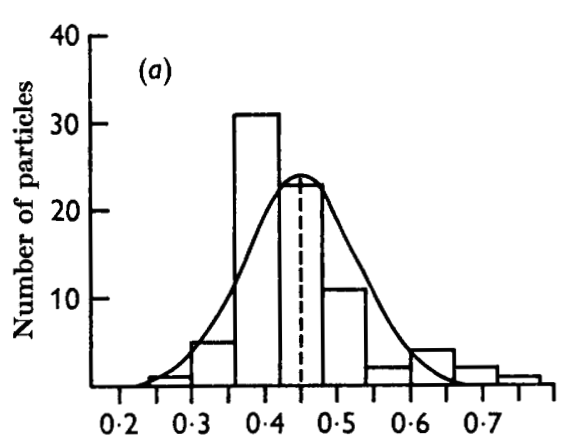

Mobility in $\mu / \mathrm{sec} . / \mathrm{V} / \mathrm{cm}$. towards anode

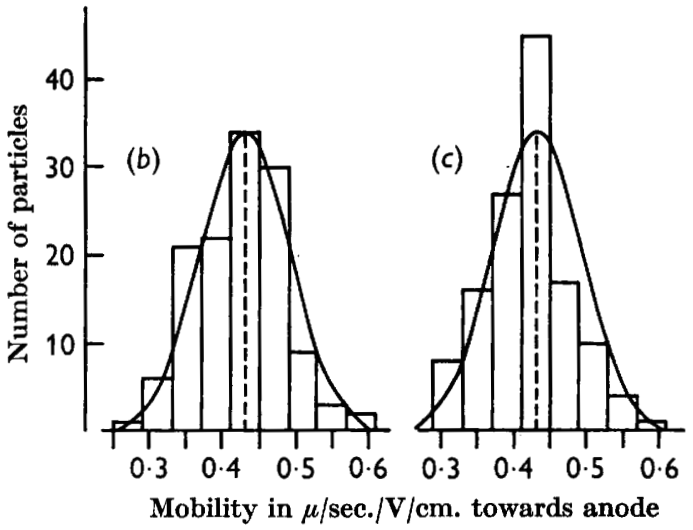

Fig. 3. Histograms of frequency of individual particle mobilities in $\mu / \mathrm{sec} . / \mathrm{V} / \mathrm{cm}$. (towards anode) in egg-grown vaccinia preparations together with the corresponding normal distributions calculated from the standard deviation (s.D.) for $(a)$ initial preparation, s.D. 0.08, (b) an intermediate preparation, s.D. 0.06 (2 phosphate-sucrose cycles), and (c) a final preparation, s.D. $=0 \cdot 06$ ( 3 phosphate-sucrose cycles).

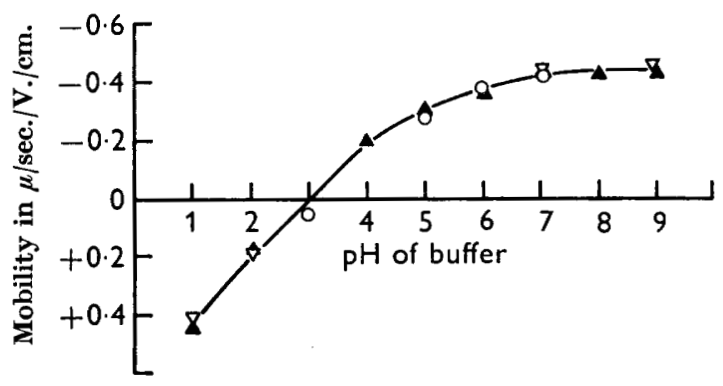

Fig. 4

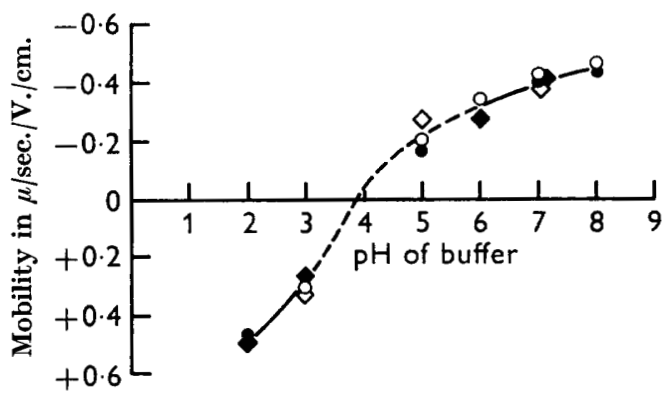

Fig. 5

Fig. 4. Mean mobility against pH behaviour for final preparations of rabbit-grown vaccinia at $25^{\circ}$, in media molar to sucrose and of ionic strength $0 \cdot 05$. O, RA 14, s.D. 0.05; $\triangle$, RS 15, S.D. 0.05; $\Delta$, RS Porton, s.D. 0.05.

Fig. 5. Mean mobility against $\mathrm{pH}$ behaviour for final preparations of egg-grown vaccinia at $25^{\circ}$, in media molar to sucrose and of ionic strength $0 \cdot 05$. Mobility in $\mu / \mathrm{sec} . / \mathrm{V} . / \mathrm{cm} .$, - ve towards anode, + ve towards cathode, s.D. 0.06 at pH \%. O, ES 13; $\bullet$, ES $9 ; \diamond$, EA 14; $\diamond$, EA 10.

\section{Vaccinia virus}

Preparations of this virus also were purified to limiting values for the standard deviation and the mean mobility at $\mathrm{pH} \%$. Crude virus material again showed a wider distribution of particle velocities than final preparations and this is illustrated by the histograms and calculated Normal distributions of Fig. 3. Final preparations of rabbit-grown vaccinia virus, including material kindly supplied by Dr H. T. Zwartouw and purified by the method of Zwartouw et al. (1962) gave closely reproducible results and a definitive mobility against $\mathrm{pH}$. The results for 
preparations of egg-grown vaccinia agreed well inter se and also agreed with rabbit-grown material at $\mathrm{pH} 7$. At more acid $\mathrm{pH}$ values some variation was shown and the egg-grown material differed from rabbit-grown virus (Fig. 5). Limiting standard deviations for final preparations of egg-grown and rabbit-grown vaccinia virus are included in the legends to these figures.

\section{DISCUSSION}

Except for some of the crudest virus preparations, the distributions of frequency of particle velocities were always unimodal and narrowed with purification. The narrowness of the distributions for final preparations and the reproducibility of results at $\mathrm{pH} 7$ gives confidence that the particles in their populations were all of the same kind. This general result would be unlikely had any appreciable host-cell substance remained on the surface of the particles.

The mobility/pH curves are consistent with the surfaces of cowpox and vaccinia viruses being composed of lipoprotein or protein material which is slightly different for the 2 viruses. By interpolation and observation the isoelectric point in molar sucrose lies close to $\mathrm{pH} \mathbf{4 \cdot 3}$ for cowpox virus (both egg-grown and rabbit-grown material), to $\mathrm{pH} \mathrm{3.0}$ for rabbit-grown vaccinia virus and $\mathrm{pH} 3.8$ for egg-grown vaccinia virus. These values may have been determined in part by the sucrose added to reduce Brownian movement.

In the case of vaccinia the mobility at $\mathrm{pH} 7(-0.42- \pm 0.05 \mu / \mathrm{sec} . / \mathrm{V} / \mathrm{cm}$. $)$ may be compared with values obtained by the Tiselius method in buffers alone. Thus Shedlovsky \& Smadel (1940) reported a value of $-1.0 \mu / \mathrm{sec} . / \mathrm{V} / \mathrm{cm}$. in buffer of ionic strength 0.02 and in the presence of a small amount of protein, while McFarlane (1940) also obtained an approximate mobility of $-1 \mu / \mathrm{sec} . / \mathrm{V} / \mathrm{cm}$., but in phosphate buffer of ionic strength 0.05 with no protein added. Since the viscosity of water at the temperature of Tiselius measurement is about 1.7 centipoise and molar sucrose has a viscosity of about 3.0 centipoise at $25^{\circ}, \mathrm{McF}$ arlane's value would correspond to a mobility of approximately $-0.55 \mu / \mathrm{sec} . / \mathrm{V} / \mathrm{cm}$. in molar sucrose at $25^{\circ}$ if all other factors, including particle charge and size remained constant. However it is clear, both from the ultracentrifuge studies of Smadel, Pickels \& Shedlovsky (1938) and from the partition experiments of McFarlane et al. (1939), that vaccinia particles are hydrated in aqueous suspension and that this hydration is reduced in the presence of sucrose. On the minimal hydration consistent with the findings of Smadel et al. there would be a decrease of about $8 \%$ in the effective particle radius on going from water to molar sucrose. This would tend to increase the mobility in molar sucrose above -0.55 unless compensated by a decrease in effective charge, which might occur in the presence of molar sucrose and/or the change in the buffer system, or in some of the other factors detailed in the general equation relating particle velocity and charge as derived by Henry (1931).

The chemist authors are indebted to the War Office and the Microbiological Research Establishment (Porton) for a grant which made this work possible. They are also indebted for hospitality to Professor A. W. Downie, F.R.S., from 
whom the authors have received helpful criticism. The authors appreciate Dr H. T. Zwartouw's helpfulness in supplying a sample of rabbit-grown vaccinia virus purified by his technique.

\section{REFERENCES}

Brinton, C. C. \& Lauffer, M. A. (1959). The electrophoresis of viruses, bacteria and cells, and the microscope method of electrophoresis. In Electrophoresis. Ed. by M. Bier New York: Academic Press.

Douglas, H. W. (1955). Electrophoretic studies on bacterial spores. Trans. Faraday Soc. 51, 146.

Dougras, H. W. (1957). Electrophoretic studies on spores and vegetative cells of certain strains of B. megaterium, B. subtilis and B. cereus. J. appl. Bact. $20,390$.

EPSTEIN, M. A. (1958). Investigation into the purifying effect of a fluorocarbon on vaccinia virus. $B r . J$. exp. Path. 39, 436.

Grspen, R. (1952). Silver impregnation of smallpox elementary bodies after treatment with xylol. Antonie van Leeurvenhoek, 18, 107.

Henry, D. C. (1931). Cataphoresis of suspended particles. I. The equation of cataphoresis. Proc. roy. Soc. A, 133, 106.

McFardane, A. S. (1940). The electrical double layer and virus stability. Trans. Faraday Soc. 36, 257.

McFarlane, A. S., McFartane, M. G., Amies, C. R. \& Eagres; G. H. (1939). A physical and chemical examination of vaccinia virus. Br. J. exp. Path. $20,485$.

Michaelis, L. (1931). Der Acetat-Veronal Puffer. Biochem. Z. 234, 139.

Miluer, G. L., Lauffer, M. A. \& Stanley, W. M. (1944). Electrophoretic studies on PR 8 influenza virus. J. exp. Med. 80, 548.

Shedlovsky, T. \& SMAdel, J. E. (1940). Electrophoretic studies on elementary bodies of vaccinia. J. exp. Med. 72, 511 .

Smadel, J. E., Pickels, E. G. \& Shedlovsky, T. (1938). Ultracentrifugal studies on the elementary bodies of vaccine virus. II. Influence of sucrose, glycerol and urea solutions on the physical nature of the vaccine virus. J. exp. Med. 68, 607.

Zwartouw, H. T., Westwood, J. N. C. \& Appleyard, G. (1962). Purification of pox virus by density gradient centrifugation. J. gen. Microbiol. 29, 523. 